\title{
Temporary Protection and the Refugee Convention in Australia, Denmark, and Germany
}

\author{
Fethi Mansouri, Michael Leach, And Amy Nethery
}

\section{Abstract}

This paper reports on a comparative study of temporary protection (TP) mechanisms in Australia and selected European jurisdictions. Specifically, it analyzes policy developments and trends in the use of TP mechanisms in Denmark, Germany, and Australia through a systematic examination of the evolution of "substitute protection" mechanisms; their implications for "effective protection" and their impacts on key stakeholders. The policy analyses are augmented by interviews and survey questionnaires with key NGO service providers in the three target jurisdictions. The paper argues that the traditional link between Refugee Convention protection and national territorial jurisdiction and responsibility is being undermined by extraterritorial processing and offshoring arrangements.

\section{Résumé}

Cet article rapporte une étude comparative des mécanismes de la protection temporaire des réfugiés en Australie et dans certains pays européens. Plus précisément, on y analyse l'évolution des politiques et les tendances du recours à la protection temporaire au Danemark, en Allemagne et en Australie par le biais d'un examen systématique de l'évolution des mécanismes de la "protection de remplacement", de leurs conséquences pour la "protection effective " et de leurs impacts sur les principales parties prenantes. L'analyse des politiques est complétée par des questionnaires d'enquête et des entretiens avec les principaux prestataires de services non gouvernementaux dans les trois pays à l'étude. On propose que le lien traditionnel entre la protection accordée par la Convention sur les réfugiés, la responsabilité et la compétence territoriale est mis à mal par le traitement extraterritorial des réfugiés et les modalités de leur délocalisation.

\section{Introduction}

The 1951 Convention relating to the Status of Refugees, henceforth Refugee Convention, and other associated standards may be seen as critical elements of liberal internationalist aspirations for universal human rights protection in the post-World War II era. These standards are based on the principle that justice as a dimension of citizenship rights needs to be extended to a global sphere rather than remain confined within the boundaries of a nationstate. Globalization is seen to have shifted the role of the state, creating challenges to its power from global markets, intergovernmental organizations, and NGOs; ${ }^{1}$ undermining macroeconomic management (thus increasing public insecurity); and reasserting of the politics of the border. ${ }^{2}$ The attempt by Australia and other western governments to deter, detain, and deport those entering "through the back door" ${ }^{3}$ is seen by some as a move away from a rights-based liberal internationalism towards exclusionary nationalism or a "particularist internationalism" 4 which redefines asylum as a political benefit bestowed by the host state, rather than a human right invoked and accessed by individuals irrespective of their mode of entry. ${ }^{5}$

The increasing restrictiveness of asylum policies in western countries is part of a broader trend that has existed throughout the history of western humanitarianism where interventions have been made on a "selective," primarily self-interest basis. ${ }^{6}$ The relatively unified nature of restrictive asylum policies is seen to arise from the sharp increase in asylum claims since the 1980 s in western countries, ${ }^{7}$ the loss of ideological prestige that granting asylum gave to host societies after the end of the Cold War, ${ }^{8}$ and the decline in resettlement opportunities that occurred in the aftermath of the international economic recession and the changed labour requirements of globalization. ${ }^{9}$ It is within this historical framework that more restrictive asylum policies such as temporary protection (TP) have recently been adopted in 
many western countries including Australia that alter the definition and application of "effective protection" 10 as originally conceived in the 1951 Refugee Convention.

Indeed, one of the most striking features of the international refugee regime over the last twenty-five years is the development of alternative forms of protection to the 1951 UN Convention on Refugees. ${ }^{11}$ Australia, Denmark, and Germany are three countries that in recent years introduced temporary protection regimes for Convention refugees as a keystone asylum policy. This article assesses the impact of TP in each of the three countries. It analyzes policy developments and trends, and then examines how these policies affect two main stakeholders: refugees, and nongovernmental organizations that provide support services to refugees.

\section{Background: Temporary Protection and the Refugee Convention}

Between 1999 and 2005, Australia, Germany, and Denmark introduced policies mandating initial periods of temporary protection for Convention refugees. In 1999 Australia instituted a policy of providing three-year temporary protection visas (TPVs) to all asylum seekers arriving without a valid visa and later found to be Convention refugees. From 2002 in Denmark, and 2005 in Germany, all refugees have been subject to an initial period of temporary protection: for seven years in Denmark and three years in Germany. Following the election of a centre-left government in November 2007, Australia abolished the temporary protection visa regime in May 2008.

While the three countries discussed in this paper are all signatories to the Refugee Convention, each sits within a distinct context of regional and international refugee law. Australia draws on the Refugee Convention and other international treaties such as the International Convention on Civil and Political Rights (ICCPR) as the context for the development of its domestic refugee policy. Germany's refugee policy is developed with reference to both the Refugee Convention and the still-evolving EU-orchestrated Common European Asylum System. The Common European Asylum System includes the Schengen Agreement, the Amsterdam Treaty, and the Dublin Regulation, each of which, although careful not to breach the Refugee Convention, restricts the ability for asylum seekers to move within Europe. Seeking more control over asylum seekers entering its country, Denmark has opted out of the Common European Asylum System, though it remains a party to the Dublin Regulation and Schengen Agreement.

Historically, the concept of temporary protection has been seen as valid in cases of mass refugee movements, when individual status determinations are impractical in the short term and temporary group-based protection is appropriate. In western jurisdictions, prior to 1999, temporary protection was typically employed to meet interim protection needs in situations of "refugee catastrophes," 12 or for complementary protection purposes, where an individual application for refugee status has been rejected but the person is found to be at risk of human rights abuse. ${ }^{13} \mathrm{By}$ contrast, this paper focuses on "substitute protection": 14 the recent application of TP to individually assessed Convention refugees in some western jurisdictions as a restrictive mechanism to reduce refugee rights and prevent integration. While "substitute" protection for Convention refugees does not breach a signatory state's non-refoulement obligationsprovided precautions are taken ensuring that the refugees will be returned to a safe environment when the period of temporary protection ceases-these newer TP regimes commonly confer fewer rights on Convention refugees. ${ }^{15}$ For Fitzpatrick, where TP is offered as a "diluted substitute protection for Convention refugees," 16 it should be seen as a threat to the 1951 refugee regime.

\section{Methodology}

This paper reports on a systematic comparative examination of the evolution of the temporary protection mechanisms in Australia, Germany, and Denmark. It evaluates the implications of these policies for the 1951 Refugee Convention, and also the impact of various EU agreements on the European countries. The policy analysis is augmented by semi-structured interviews and surveys of key non-governmental organizations (NGOs) and service providers in Australia, Denmark, and Germany. The interviews were conducted and directed towards finding out the impact of temporary protection on refugees, on the services refugees required, and on the ability of NGOs to meet this need. Particular attention was paid towards the impact of the policy on protection status and permanency; access to settlement services and programs; education, health, and work rights; and cessation, repatriation, and integration mechanisms at the end of the temporary protection. The policy developments are examined in the context of corresponding political tensions between the uses of temporary protection to meet the aims of both liberal-humanitarian and restrictive policy impulses. The latter refers to the tension between border protection harmonization initiatives on one hand, and the maintenance of more restrictive national regimes articulated with an increasing "securitization" agenda on the other.

\section{The Three Case Studies}

Australia

Australia's humanitarian program resettles approximately 13,000 refugees each year. This quota comprises 
two categories. The "refugee category" resettles 6,000 "offshore" refugees from UNHCR camps in areas assessed to be of greatest need. A further 7,000 resettlement places are set aside for the Special Humanitarian Program (SHP) (also "offshore") and for "onshore" arrivals. Offshore refugees are granted the full range of settlement services and enjoy the same range of rights as Australian nationals. Since the 1970 s, the arrival of so-called "onshore" refugees, particularly "unauthorized" arrivals who arrive by boat without a visa of any kind, has caused a problem for successive governments. Onshore refugees are those who invoke their right to seek asylum once they have entered the migration zone. Although under international law this group is the only group that Australia is legally obliged to offer protection to, the unregulated nature of their arrival has been regarded as a problem by successive governments. Australia's temporary protection policy, introduced in October 1999, aimed to control and limit the arrival of onshore asylum seekers popularly referred to as "unauthorized" boat arrivals.

From October that year, all asylum seekers who entered Australia's migration zone without a valid visa of any kind, but who were found to satisfy Convention criteria, were initially granted temporary protection, before being able to apply for a permanent visa after three years. In September 2001 the policy was strengthened by the "seven-day rule," which declared asylum seekers who had spent longer than seven days in a country "where they could have sought and obtained effective protection" 17 were ineligible for the award of a permanent visa at any time. Given that onshore asylum seekers commonly take long and perilous journeys to Australia, and normally spend time en route in non-signatory countries such as Indonesia or Malaysia, this opened the prospect of "rolling" temporary protection periods for most onshore refugees.

The TPV was one aspect of a broad border protection strategy to "deter and deny" access of onshore asylum seekers to Australia's protection obligations. In 2001, the Australian government introduced a range of other border protection strategies, in addition to the mandatory detention regime in place since 1992. These included the positioning of immigration officers at domestic and international airports to detect people travelling on false documentation and strengthening the power of the Australian Navy to patrol the waters to Australia's north. Other restrictive strategies included "Operation Relex," which authorized the Navy to drag vessels approaching Australian waters back into Indonesian waters. They also included the collaboration of Australian and Indonesian intelligence to disrupt the activities of people smugglers in Indonesia.

The Pacific Solution was another strategy aimed at deterring potential asylum seekers. The policy was introduced in October 2001 when the Migration Act was amended to excise a number of outlying islands from Australia's migration zone. All asylum seekers who arrived by boat on these excised territories were held in detention centres on Nauru (and until 2005, Papua New Guinea), while their applications for asylum were processed. Such asylum seekers had no guarantee of being settled in Australia even if granted refugee status. Taylor ${ }^{18}$ reported that, without access to judicial and administrative appeal procedures, refugee determination decisions on Nauru were more likely to be negative than those on the Australian mainland. These factors highlighted the increasingly limited avenues for seeking asylum in Australia between 1999 and 2007. A total of 10,800 TPVs were issued over this period.

In November 2007 a new Australian Labor Party (ALP) federal government was elected, ending eleven years of conservative Liberal-National party rule. In May 2008, the new ALP government announced that the TPV regime would be abolished and that future onshore asylum seekers found to have Convention refugee status would receive Permanent Protection Visas (PPVs). Existing TPV holders would receive "Resolution of Status" (subclass 851) visas, with equivalent rights to permanent protection visa holders. Eligibility for this latter visa was signalled in order to prevent exisiting TPV holders from going through the status redetermination processes required for the granting of a PPV. Also abolished were the temporary humanitarian visas (THV) routinely granted to offshore "Pacific Solution" asylum seekers who were later accepted by Australia under the Special Humanitarian program. Existing THV holders would likewise receive a permanent "Resolution of Status" visa. The Department of Immigration and Citizenship overview of the changes noted the following rationale for the abolition of the TPV regime: ${ }^{19}$

TPVs and THVs were introduced by the previous government to discourage people smuggling activities resulting in unauthorised boat arrivals (UBAs) and to discourage refugees leaving their country of first asylum. The evidence clearly shows TPVs did not have any deterrent effect. In fact, there was an increase in the number of women and children making dangerous journeys to Australia.

The commitment to shut down the "Pacific Solution" camps in Nauru and PNG was also maintained, with the last asylum seekers from Nauru resettled in Australia in January 2008. From this time, however, "offshore entry persons" have been processed on the distant Australian territory of Christmas Island. The Labor government has maintained the excision of Christmas Island and other territories from the migration zone, and as such, continues to process "offshore 
entry persons" in a way that limits their access to the Refugee Review Tribunal or other forms of judicial review.

\section{Denmark}

Denmark was the first nation to become a signatory to the Refugee Convention in 1952. It has long been regarded as having a generous asylum policy, primarily due to the implementation of alternative forms of protection status, including the so-called "de facto" status, under which asylum seekers who did not meet the strict criteria of the Refugee Convention could be granted protection if their situation warranted it. The de facto category included those avoiding military service, escaping situations of civil war, or subject to persecution for their gender or sexuality. Despite these generous policies, Denmark has not seen the mass influx of refugees experienced by other European countries.

A shift in public opinion over immigration in Denmark contributed to a change of government in November 2001. Legislative changes to immigration policy introduced in July 2002 sought to reduce the numbers of asylum seekers gaining entry to Denmark. These changes had three fundamental elements: ${ }^{20}$

Denmark's commitment under international conventions must be honoured. The number of foreigners entering Denmark must be limited and stricter requirements must be introduced with regard to their obligation to support themselves. The refugees and immigrants already living in Denmark must be better integrated and get work more quickly.

A new asylum policy arose through a series of minor reforms, rather than one major legislative package. As Michael ${ }^{21}$ from the Danish Institute for Human Rights put it, "We have seen one new piece of legislation after the other." From 2002, various changes were made to three key pieces of legislation: the Integration Act, the Aliens Act and the Nationality Act. Thoralf from the Danish Refugee Council notes, "We've seen changes to the Aliens Act on a steady half-year basis over the last few years. So you get a tightening up just a little bit every six months."

Though outside the EU asylum framework, Denmark is signatory to the Dublin Convention, which results in refugees having to conceal their route to Denmark, as the interviewees point out. Katrin notes, "It will first be asked whether they should be assessed in another country. If they are not identified or if their travel route is unclear, then they can be detained. These are the main reasons for detaining people."

Under the 2002 changes, the previous de facto status was abolished and replaced with "Status B" category. This new category continues to recognize the need for some forms of
non-Convention protection under other sources of international law, such as the European Convention on Human Rights, and offers protection against torture and the death penalty. However, unlike the previous de facto status, Status $\mathrm{B}$ does not encompass persons fleeing civil war or forced military service. Katrin from the Danish Refugee Council explains that this legislation has particularly affected asylum seekers from Bosnia and Somalia, who would previously have been granted de facto status but are now ineligible.

One of the key changes in 2002 related to the dramatic increase in the length of the temporary protection visa period. Previously, refugees held a three-year temporary protection visa, and if found in need of further protection, were granted a permanent residency visa. In 2002, the newly elected government increased the length of the temporary visa to seven years, after which refugees could be granted a permanent residency and become eligible for Danish citizenship after nine years. The 2002 changes also introduced a series of limitations to family reunion rights. Family reunion was perceived by the Danish public to be a "backdoor route for spouses and their children to take advantage of Denmark's generous social benefits." 22 Under the new regime, both spouses must be twenty-four years old or older, and a Danish citizen cannot sponsor a parent aged sixty years old or older. If a Danish citizen wants to sponsor a spouse, the couple must be able to prove that their "ties" are closer to Denmark than any other country. The Danish spouse must pay a deposit of 6,700 euros and have a place to live. If the marriage does not last seven years, the foreign spouse may be required to leave Denmark. Other changes made in the 2002 legislation circumscribed the ways asylum seekers can lodge applications for protection. Asylum seekers can no longer lodge their applications at Danish embassies, but must be present in Denmark to seek protection.

Following the introduction of the new changes, Denmark experienced a significant decrease in the numbers of asylum seekers; in the same year, Norway experienced a large rise in asylum applications. This would circumstantially suggest that the temporary protection regime has impacted upon the numbers of people seeking asylum to Denmark. Approval rates for asylum applications also decreased following the introduction of the new laws. In 2005, the Danish Immigration Service (DIS) rejected approximately 90 per cent of asylum applications in the first instance, an increase from 50 per cent in $2002 .^{23}$

Montgomery and Foldspang argue that recent refugee determination decisions also demonstrate a systemic bias against applications from Muslim asylum seekers. ${ }^{24}$ Their study concludes that families who practised a religion other than Islam were eight times more likely to receive a residency permit than Muslims. Also more likely to succeed 
in gaining residency were families in which the father had higher levels of education and was employed in administrative work rather than manual labour. They argue that without greater transparency, the asylum decision process "seems to favour the selection of socially and culturally well situated refugees, while human rights violations seem to play a diminishing role." 25

In terms of welfare support, the payments available to temporary protection refugees in their first seven years stands at two-thirds of the amount received by other members of the community, including refugees with permanent protection. While there is an additional payment for families with children, it is capped at two children, so that larger families receive no further benefit. The differential payment is ostensibly designed to encourage refugees into paid work. Despite this approach, only 20 per cent of refugees were in paid employment in 2003 after the instigation of the policy, compared with 25 per cent in $2002 .^{26}$

The Danish policy of geographical dispersal of refugees is based on the "Scandinavian ethos of egalitarianism" whereby all regions in Denmark should equally share the "burden" of refugee settlement. ${ }^{27}$ While the basic concept of dispersal has support from the NGOs, an unnecessarily strict administration of the policy has negatively impacted on refugees experiences in their new country (Kristofer interviews). Many asylum seekers come to Denmark through social or familial networks, Kristofer explained, and the policy of dispersal does not recognize these networks. Refugees are thus often isolated from other contacts, even family members, who live in other areas of Denmark. Similarly, Wren argues that dispersal is determined by housing availability and demand, and commonly results in refugees being placed in areas of social deprivation, lacking adequate social opportunities, and settlement services. ${ }^{28}$

\section{Germany}

At the end of World War II, Germany introduced an asylum regime that was the most generous in the western world. Enshrined in the German constitution, or the Basic Law, the asylum policy ensured that all those who experienced persecution could seek asylum in Germany. Article 16(2)2 states: "Persons persecuted for political reasons enjoy the right of asylum." Schuster explains that the German Basic Law was a strong symbol of cleavage from the Nazi past, and contained within it all the universal liberal norms and values that had been "repressed" by Nazi rule. ${ }^{29}$ She explains, "By enshrining these norms in the constitution, it was hoped that they would ensure the preservation of the liberal character of the new republic." 30 Thus, the Article in the Basic Law maintained Germany's remarkable liberal rule on asylum seekers and gave "unmatched protection"31 until 1993.
No other aspect of the constitution came to cause as much controversy. ${ }^{32}$

In the late 1980s and early 1990s, increasing antiforeigner hostility and violence focused on refugees. In response, the government implemented measures in 1992 to limit the ability of refugees to seek asylum in Germany. While clause 16(a)(1) remained unchanged, it was joined with a number of clauses significantly limiting the scope of the original policy. In particular, 16(a)(2) now states that the right to asylum

may not be invoked by a person who enters the federal territory from a member state of the European Communities or from another third state in which application of the [Refugee Convention] is assured ... [in these cases] measures to terminate an applicant's stay may be implemented without regard to any legal challenge that may have been instituted against them.

This clause has become known as the "Third Country Rule," which significantly altered the conditions under which people could seek asylum and limited the power of the courts to challenge its operation. Temporary protection legislation was introduced in January 2005. Under this policy, those assessed to be Convention refugees are granted a residence permit, valid for three years. After this time, the refugee's case will be reassessed, and if the refugee is found to be in need of ongoing protection, a permanent residency visa is granted.

During the initial three-year period, a residence permit can be revoked at any time if the asylum seeker has committed a crime, has engaged in "hate-preaching," or is found to have threatened German national security. Importantly, for Convention refugees, the permit can also be revoked if they are deemed to come from a country that is subsequently declared a "safe country of origin." The notion of "safe country of origin" was developed in Europe in the early 1990s as part of the strategy of providing protection to Bosnian refugees. Since 1992, Germany has had a list of "safe countries of origin" which is regularly reviewed and updated as part of its domestic law. To date, EU members have been unable to come to a consensus on safe countries to include a similar list in the Common European Asylum System.

As with Australia and Denmark, Germany's temporary protection regime is part of a broader suite of measures that aim to decrease the number of asylum seekers entering its territory. As a party to the EU asylum regime, asylum seekers to Germany are subject to three main EU agreements. The Schengen Agreement, which came into force in 1995, abolished checks at common borders of the signatory countries, meaning greater freedom of movement for EU citizens. For those from outside the Schengen area, the Agreement 
means harmonized visa requirements, standardized checks at borders, and greater collaboration to combat crime. The resulting increased regulation of the borders of the EU has become known as "fortress Europe." The Amsterdam Treaty (1999) incorporated the Schengen agreement into European Union law. It established the criteria and mechanisms for determining which Member State is responsible for considering an asylum application, and outlined minimum standards for all aspects of the asylum process, including minimum standards for temporary protection. Finally, the Dublin Regulation, or Dublin II (2003), aims to prevent asylum seekers from submitting multiple applications for asylum within the Schengen area. Under the Dublin Regulation, asylum seekers are processed in (and if necessary returned to) the country deemed responsible for processing their application, usually the first European country through which the asylum seekers passed. The Dublin Regulation and Amsterdam Treaty, therefore, aim to limit so-called "asylum shopping."

Since the mid-1980s, only 5 per cent of asylum seekers to Germany have been assessed to meet the requirements of the Refugee Convention. ${ }^{33}$ In 2002 and 2003, the grant rate for Germany was 3 per cent and 2 per cent respectively. ${ }^{34}$ Many rejected asylum seekers stay in Germany on Duldung, or "tolerated" status, for many years. Duldung is a "technical" rather than formal legal category, and is applied in cases where deportation has to be postponed for administrative or legal reasons. It is the weakest form of "protection" offered by the German state, and does not grant any particular right or duration of stay. Rather, if obstacles to deportation are found to remain, Duldung status is renewed every six months. As a result, "Geduldeten" may live in Germany for many years, in a phenomenon referred to as Kettenduldung, or "chain"-Duldung.

There are an estimated 200,000 people with Duldung status living in Germany, some of whom are estimated to have been residing on Duldung status for over sixteen years. Geduldeten have restricted access to employment and receive state benefits at a rate 20 percent below conventional social welfare payments. They cannot work for a year after the initial grant of Duldung status, and work permits stipulate the number of hours that they may work. Children can go to school, but cannot access vocational training. Finally, Geduldeten do not have rights to family reunion. ${ }^{35}$ As in Denmark, refugees and Geduldeten in Germany are allocated to a town in which they may live and work. Once allocated, refugees and Geduldeten are not permitted to travel further than thirty kilometres from the town, and it may be considered a breach of their residency permit if they do. There are legislative exceptions to this rule if the asylum seeker has found work in a different area.
In 2007, legislative changes were introduced designed to reduce the numbers of Geduldeten. The changes grant people with Duldung status who have lived in Germany for eight years, or six years if they have children, a temporary residency permit on 1 July 2007. At the end of 2009, these Geduldeten will be granted permanent residency if they have kept a clean criminal record; achieved independent financial security, regular employment, a high level of German language abilities, integration into German society, and adequate accommodation according to the size of their family; and ensured regular school attendance for children. As part of the agreement, the amount of social assistance provided to Geduldeten is reduced. If these criteria are not met by the end of 2009, the consequence will be deportation. ${ }^{36}$ According to the Migration Policy Institute, ${ }^{37}$ this may apply to approximately 50,000 of the 200,000 Geduldeten currently living in Germany.

\section{Research Findings}

Semi-structured interviews with NGO representatives working with refugees on TP were conducted in 2006 and 2007. Three NGOs from Germany and four from Denmark took part in the study. ${ }^{38}$ These were compared with existing Australian data compiled by the authors over several previous studies. ${ }^{39}$

Five key themes emerged from the interviews. First, TP refugees in all three countries experienced social and financial difficulties occasioned by the TP policy. Second, the experience of temporary protection has led to a heightened sense of uncertainty in refugees' lives. Third, the lack of rights to family reunion under temporary protection regimes has been a prime source of hardship for TP refugees. Fourth, the interviewees were keenly aware of a new and restrictive political climate on refugee issues. Finally, NGOs experienced great challenges in meeting demands for their settlement support services and in maintaining their independence from government when advocating for refugee rights.

\section{Social and Financial Difficulties for Refugees}

NGO respondents from all three countries were concerned about the everyday financial and social pressures imposed on refugees under TP regimes. In Germany, Jurgen from Flüchtlingsrat Berlin noted that both refugee policy and the broader economic climate made it difficult for asylum seekers to live in Germany. Geduldeten may work after twelve months of being granted a residence permit, but only if they can secure a job that no other German unemployed person can perform. The result of this policy, according to Jurgen, is that 99 per cent of people with Duldung status are unemployed and dependent on social aid. 
In Germany, Convention refugees have entitlement to the full rate of public assistance. Asylum seekers and Geduldeten, however, receive 80 per cent of the public assistance paid to unemployed German nationals, or less if they are part of the group given temporary residency visas in July 2007. In principle, this assistance is not given in cash, but in kind, such as the provision of medical treatment. Jurgen explains:

This social aid from the state is lower than the social aid for Germans. They get only 225 Euro a month, if they get it in cash. Germans get 345 Euro plus housing and medical care. But the law says that asylum seekers should get food and clothes vouchers, not cash. So in many cases they only get pocket money of 40 Euro per month for an adult, for using public transport. Do you know how much public transport is? 4 Euro for a return ticket. So 36 is left for the month. And then you need to pay the phone ...

Both Germany and Denmark have settlement policies requiring geographic dispersal, with the aim of shifting migrants away from the metropolitan centres where they might form ethnic "ghettos." Germany's dispersal policy restricts the movement of refugees and Duldung to an area of thirty kilometres around their homes. Refugees and Duldung are fined, and refugees may face problems with gaining permanency, if they breach this restriction. Jurgen argues that these policies limit the ability of refugees to integrate, by limiting employment and educational options, and also limit the ability for refugees to visit friends and family in other areas of Germany. In Denmark, Kristofer from the Danish Institute of Human Rights agrees with the general idea of geographic dispersal, but argues that it is too strictly administered:

I think it's working to some extent ... I'm not against it per se, otherwise everybody gets stuck in Copenhagen ... But it has become extremely rigid, far too rigid, in that you are stuck in those places and families cannot get together.

Some interviewees saw positive effects, as some rural centres were benefiting from the increase in population and a revitalized community. As Karita from the Danish Red Cross notes:

What happened over here in the remote northern part of Jutland, they found out that the asylum seekers who went to those centres went to shops and spent money there, and a few of the citizens could go and work at the asylum centres. When the immigration service came and said they were going to close down these centres because it is a stupid place to have asylum seekers, the whole village said "please no, don't close our centre, these are our asylum seekers.”
A similar phenomenon of "regional renewal" occurred with TPV holders in rural Australia, with high profile rural community campaigns leading to the 2004 changes in the Regional Sponsored Migration Scheme, which allowed TPV holders in rural areas to gain permanent work visas and fill lower-skilled job vacancies, without first leaving the country and re-entering under a new "offshore" visa.

Interviewees also highlighted the lack of integration opportunities for TP refugees. In Denmark, children with temporary protection have the same access to education as Danish citizens, but for the first few years many of them attend school at the reception centres where they are accommodated, where they can only interact with other refugee children. Emilia and Henderson from the Research and Rehabilitation Centre for Torture Victims observe that this policy is in itself a barrier to integration. As Emilia argues, "You build up a system that prevents integration, and then you say people have to be integrated." Henderson continues, "Then you turn it around and say, well, there is something inherently wrong with you, you cannot integrate. You have a problem, it is within you."

\section{Uncertainty in Refugees' Lives}

NGO respondents in Australia, Denmark, and Germany each highlighted the impact temporary protection was having on the psychological well-being of refugees. Extended periods of temporary protection under the new regulations, Henderson says, are "creating a 7 year existential moratorium." Similarly, Emilia mentions cases of "complicated traumatic stress." In Denmark, in addition to temporary protection refugees, there is another group of refugees living in great uncertainty, the so-called "phase 3 rejected asylum seekers." This group are in a parallel situation to the Geduldeten in Germany-they are designated for removal from the country, but their immediate deportation is not possible for legal or technical reasons. As noted above, many asylum seekers from Somalia not granted protection under the new status B law are in this category. These phase 3 rejected asylum seekers are accommodated in the two "departure centres" at Sandholm and Avnstrup. As Katrin from the Danish Refugee Council notes:

They can't get formal protection now, but still they can't be sent back. So they are sitting in the Avnstrup and Sandholm camps waiting. They cannot be sent out by force, because the police even do not dare to go there themselves, they do not dare escort them back to Somalia.

Regulations introduced in Germany in 2005 allow the government to revoke the refugee status of refugees who have been in Germany for less than three years, if the 
situation in the country of origin is found to have changed. Where most countries consider past persecution sufficient reason for granting ongoing refugee status, TP jurisdictions commonly hold that the granting of a refugee visa may not be the "last word" on one's status. Since 2005, 18,000 Iraqis who had initially been granted refugee status in Germany have had their refugee status revoked on the basis of changed political conditions in Iraq. ${ }^{40}$ As Johanson, from Germany's Centre for Treatment of Torture Victims, explains,

They are saying people got political asylum because Saddam Hussein was in power and persecuting them. So he is no longer in power so there is no longer any danger of being persecuted, but in fact there is still a danger of being a victim of the war situation. For these two different situations you now get different statuses.

According to Johnson, many Iraqi refugees are still "afraid" that they may be eventually returned to Iraq. Those who have had their refugee status revoked but still hold a residency permit may stay in Germany until it expires, after which they are deported or granted Duldung status. The policy introduced in 2005 to grant permanency to some Geduldeten exacerbates the sense of uncertainty for people with tolerated status. Rather than issue an amnesty to all Geduldeten, the 2005 policy allowed each state to set up a commission to assess the humanitarian status of individual Geduldeten. These state commissions, made up of representatives from NGOs, would recommend to the Federal Minister of the Interior that an individual should be given permanent protection. Although this has benefited some individuals, Jurgen explains that he "has a problem with the justice, it is somehow extralegal. I would prefer if you allowed this for everybody who has been here for 5 years, it is more just."

One problem with this policy is that each federal state uses this policy differently. Berlin has put forward about 1,300 people for permanent status, of whom 650 have been successful. Other states have been less proactive about endorsing asylum seekers to the Minister of the Interior. The federal state of Bavaria has not set up a commission, and no individuals have been recommended to the Minister of the Interior. Johanson from the Centre for Treatment of Torture Victims in Berlin argues that granting amnesty to the large numbers of Geduldeten in Germany is "the task of the day," and that by setting up commissions to grant permanency to individuals the government has missed the opportunity to make a difference on a large scale. Jurgen agrees, arguing that this policy has served to keep the level of discussion about Duldung "low." He explains:
It gives a solution to give to cases in the newspaper, they wanted to use this to keep the discussion low. It is used for political reasons, to give something to the Churches. So each Church's most-loved refugee can get status, which is what I don't like. It discriminates against others.

\section{Right to Family Reunion}

In all three jurisdictions, the restriction of rights to family reunion had the greatest impact on refugee lives. In Australia, refugees on TPVs had no right to family reunion. For those TPV refugees who had breached the "seven-day rule" by spending more than week in a third country en route to Australia, and were therefore threatened with "rolling" TPVs from 2001, it seemed likely that they might never be entitled to bring their families to Australia. Equally, for Australian TPV holders, leaving the country to visit relatives meant relinquishing their protection status and their right to re-enter the country.

Leach and Mansouri documented the feelings of guilt and despair among male TPV holders resident in Australia who were unable to bring their immediate families to Australia. ${ }^{41}$ This policy had another impact, in that more women and children began to make the dangerous boat journey to Australia themselves. After 2001, an unprecedented number of women and children arrived by boat as exemplified by the disaster of the Suspected Illegal Entry Vessel (SIEV) X, which sank in August 2001, killing 353 of its 393 passengers. The majority of those who died were women and children, many of whom were travelling to Australia, where their husbands and sons were already resident on TPVs.

Restrictions on family reunification for refugees with temporary protection form another barrier to integration. In Germany, refugees have rights to family reunification. If their refugee visa is revoked, however, the person may stay in the country for the rest of his or her residence permit, but loses rights to family reunion. Geduldeten do not have rights to family reunion. Moreover, the policy of dispersal does not take into account the location of other relatives living in Germany, and many refugees are placed in regions a long way from family, and risk jeopardizing the grant of a permanent visa if they visit them.

With the change to asylum policy in Denmark in 2002, rights to family reunion were tightened. Refugees on temporary protection have no right to reunion with a spouse, unless the spouse proves strong ties to Denmark (the same applies to non-Danish migrants married to Danes) or are themselves assessed as refugees requiring protection from Denmark. A DK50,000 (US\$10,000) bond is required for the reunion of spouses, and the Danish spouse must not have received social assistance for the period leading up 
to the reunion. Equally, the spouse coming to Denmark must be capable of working. No spousal reunion is granted for a spouse less than twenty-four years of age, nor family reunion for parents if the parent is over sixty years of age. ${ }^{42}$ These policies restricting family reunion are, according to Kristofer, "contrary to basic human rights principles," and operate to limit the ability for refugees to integrate.

\section{Exclusionist Political Climate}

Most interviewees noted the impacts on refugees of a wider shift in the public discourses on immigration. Kristofer mentions the Danish government's overt unwillingness to commit to international standards of human rights. Similar themes were notable across the three jurisdictions.

Previous social democratic governments said we will respect our international obligations. The new party now says, well, what are our international obligations? Do we have a case for saying we will not do this? ... We want to decide how policies should be made, we are not going to ratify a new legal instrument .... So I am hearing more and more of this rhetoric about human rights being "antidemocratic," and it is always focused on foreigners.

Denmark's transformation from one of the most progressive asylum states in Europe to a "hardliner"on refugee issues had certainly resulted in decreasing numbers of asylum seekers. Katrin describes this as the impact of "the rumour about Denmark":

The rumour about Denmark and the fact that it is well known that it is difficult to get family reunion in Denmark, certainly that has had an impact ... and changed things in rather a short period. Denmark used to be known for its human rights, and now it is completely different.

Kristofer notes that "the 2002 legislation had a tremendous signal effect. This signal was picked up around the world so the number of asylum seekers dropped." In spite of this, Kristofer sees a positive side to the development-a consciousness-raising effect on the wider public, as repressive regulations have in turn "created a tremendous human rights awareness." Accordingly, representatives of the Danish Refugee Council stressed the important role of more than 2,000 volunteers who are the mainstay of settlement and integration programs, helping children with homework, running language schools, and organizing leisure and community-building activities.

A common theme in the German interviews was the observation of increased difficulties for asylum seekers to gain protection in Germany. These difficulties include physical obstacles, such as increased policing in Eastern European states. Jurgen noted that Poland and other Eastern European countries are more likely now to deport and imprison asylum seekers. He states, "Eastern Europe in the beginning of the 1990s used to be the main refugee route, and now it is really dangerous for [asylum seekers] to come this way." Similarly, the introduction of the Schengen agreement, and policies like the third country rule, makes seeking protection in Europe more difficult. At the same time, there has been significant narrowing of the refugee definition, so that the rate of those granted refugee status is only 2 to 3 per cent. Many asylum seekers who would have once received refugee status no longer fit the criteria, and some of these remain in the country under Duldung status. As Jurgen puts it, "nowhere in the world is there such a low recognition rate."

The increased difficulty in gaining access to Germany is the aim of European Union border protection policy. Johanson observes that much of the EU approach to asylum seekers has been modelled on German policies. In some cases this relationship has been the reverse; for example, the policy of revocation of protection visas was originally an EU policy that was immediately adopted by Germany. Yet Johanson also acknowledges that one aspect of EU policy has improved the situation for asylum seekers. In addition to the Refugee Convention definition of refugee status, the EU now recognizes persecution against women, and persecution by groups other than the government of the country of origin, as criteria for granting refugee status. This has improved the chances of some asylum seekers in gaining protection in Europe.

\section{Diminishing Resources for NGOs}

Like their counterparts in Australia and Germany, NGOs across Denmark feel their advocacy and settlement support work has been increasingly impeded. Kristofer, as the head of the Danish Institute for Human Rights, reported experiencing personal attacks from the Danish People's Party (DPP), one of a coalition of parties in government since 2001:

For two months if you entered into the webpage for the DPP ... you would find a picture of me. When you "clicked" on me you find a list of all the nasty things I have done in my life. So they effectively put pressure on the new government to close us down. The decision was made, but then, thanks to a lot of support internationally as well as domestically, they figured that that was not such a good idea. But the threat of closure was a very symbolic gesture from the government that demonstrated the nature of the new times.

Kristofer went on to note the growing challenges facing refugee advocates in general, including financial constraints: 
Our organisation may be a particular target, but it is more general than that ... we have never had such a difficult time in relation to freedom of expression. This is contrary to what the Prime Minister has claimed about freedom of choice ... we have never had such a difficult time, where critical voices are constantly harassed, or suffering funding cuts, and so on.

For its part, the Danish Refugee Council has had its influence in asylum determination processes severely curtailed under legislative changes made in 2002. The Council previously had two of the five chairs on the Refugee Board, which makes decisions on individual applications for asylum. In 2002, the Refugee Board was reduced from five to three members, cutting out the Refugee Council places in the process. While the Council still retains a veto right in the so-called "manifestly unfounded" procedure, it is no longer represented on the more important body with the final say in asylum decisions.

Financial restraints on NGOs have affected their ability to advocate on behalf of refugees. The Rehabilitation and Research Centre for Torture Victims now works on a "paid per session" funding arrangement, for both rehabilitation services and research projects. This has had a significant impact on the scope of the services provided. In particular, it means staff time is spent providing direct individual client services, with a diminished ability to conduct "sector advocacy" on behalf of their clients as a whole. This arrangement brought on by recent conditions attached to government funding affects 95 per cent of the Centre's budget. As such, only 5 per cent of its budget is allocated towards sector advocacy to deal with wider policy issues.

Interviewees in Germany also experienced difficulties in providing services to refugees as a result of funding and resource cuts. Johanson notes that his organization, the Centre for Treatment of Torture Victims, is one of only four that receive funding from sources other than the German government. He explains that the "increased reliance on our services" means that "we have to work very hard to meet demand."

We have very long waiting list, but we can't deliver the services that are needed by the people. We have lists on which people are waiting for 1 or 2 years. There is so much work needed apart from the psychotherapy, such as writing the psychological certificates and supporting them in their court cases as psychologists.

Two of the German NGOs also noted difficulties in maintaining independence from the government, which they regarded as essential to effective refugees advocacy. While Flüchtlingsrat Berlin receives 50 per cent of its funding from the European Commission, this money is channelled through the Federal Office for Migration in Germany, compromising the ability of the organization to maintain an independent stance. Jurgen explains:

The Office for Migration visits us once a year and asks us if we are working well. Sometimes I feel that maybe if we are more critical of them they may not fund us ... if I'm honest it is a problem to try to be $100 \%$ independent.

Similarly, Estella from Xenion, an organization that provides psychosocial help to refugees, stressed the importance of maintaining financial independence from other organizations. This is, according to Estella, "so we can say whatever we want without having to worry that the funding organisation will say 'no, we don't want that."”

\section{Conclusion}

The case studies reported in this paper illustrate some poignant aspects of the impact of temporary protection regimes in three western jurisdictions. In Australia, Denmark, and Germany, recent trends in refugee policy have two contradictory elements. On the one hand, governments have introduced strategies to reduce the numbers of refugees entering the country. On the other, each has placed increased emphasis on the socio-economic and cultural integration of refugees into the community. This paper's findings strongly suggest that, rather than facilitating this integration, temporary protection regimes have actively hindered integration in a number of key ways. Reduced access to education, health care, language tuition, and employment services all serve to limit functional economic and social settlement of refugees and radically reduce the refugees' ability to function fully and competently in their new communities. Equally, the emotional distress caused by the separation of families and the lack of certainty about the future further disables refugees' capacity to integrate. In particular, the ever present and implicit threat of forced repatriation means that TP regimes are inherently incapable of fostering psychological and cultural settlement and, more critically, are prone to political and public "controversy." 43 In all three jurisdictionsuntil the abolition of the TPV in Australia in 200844-the transition between temporary protection and permanent protection was not automatic. The refugee must meet certain criteria, including passing language tests and criminal record checks. Most importantly, the refugee must demonstrate a need for ongoing protection at the expiry of the period of TP. To do so, they must not come from a country subsequently declared a "safe country of origin." In terms of settlement support services, the research shows that that NGOs supporting refugees have found it increasingly

(C) Fethi Mansouri, Michael Leach and Amy Nethery, 2009. This open-access work is licensed under a Creative Commons AttributionNonCommercial 4.0 International License, which permits use, reproduction and distribution in any medium for non-commercial purposes, provided the original author(s) are credited and the original publication in Refuge: Canada's Journal on Refugees is cited. 
difficult to meet demands on their services, as the state has reduced rights of access to employment, provision of settlement services, and restricted access to mainstream welfare benefits.

Australian research comparing the mental health of refugees with temporary and permanent protection visas ${ }^{45}$ shows that temporary protection can impact dramatically on refugees' mental health, and that the TPV status was the greatest single contributor to post-traumatic stress disorder (PTSD). TPV holders' experiences in detention contributed to this, but current living conditions, fears of returning home, worry about the family's safety, and lack of family reunion were also major contributors to mental health decline. One Australian study indicated that TPV refugees had a 700 per cent increased risk of developing depression and post-traumatic stress disorder in comparison with PPV refugees; and that these extended periods of temporary protection operated to "lock individuals into an unresolvable future-oriented" stress, undermining standard treatments and therapies for trauma premised on a "core assumption of safety as a necessary precondition." 46 The long-term effects of an extended exclusion from settlement services, in conjunction with the impacts of initial periods of mandatory detention, remain to be seen. These effects are likely to remain critical factors in the ongoing settlement experience of former TPV holders. Similarly, in Germany, Bosnian temporary protection holders were found to have experienced a "permanent state of anxiety" as a result of their temporary status. ${ }^{47}$ This emotional distress can impact on the whole refugee experience, affecting refugees' ability to learn the host country language, to work, and to raise children in a healthy environment.

Temporary protection is one of many mechanisms for limiting refugees' access to protection, which also include extraterritorial processing and offshoring arrangements. These "substitute protection" mechanisms limit access to effective protection under the Convention. In the three countries discussed in this study, the temporary protection policies have obstructed successful integration. Policies that place limits on learning the language, that limit access to education or health care, and that restrict movement radically reduce the refugees' ability to function normally in their new communities. The emotional distress caused by the separation of families and the lack of certainty about the future further disables refugees' ability to integrate. In each case, TP policies undermine the stated goals of promoting greater integration and assimilation into the host country.

The internationalization of western refugee policy development is evident in the extent to which countries are able and willing to import harsher policies perceived to have been successful elsewhere. As Danish Refugee Council spokesperson Thoralf puts it, there is "no doubt" that the extraterritorialization phase of recent developments in asylum policy in Europe had been inspired by Australia's "Pacific Solution" arrangements. It seems likely that the "substitute protection" TP mechanisms introduced in Denmark and Germany were similarly influenced by the introduction of the Australian TPV in 1999. In this context, the dramatic decision of a new Australian government to abolish the TPV regime in 2008 is an important one, which is likely to be noticed internationally. This reform signalled the capacity of concerted domestic and international campaigns to reverse restrictive trends in Western asylum policy, held by many commentators to be "inevitable" in an age in which refugee issues are increasingly viewed through the prisms of national security and sovereignty.

\section{Notes}

1. Alison Brysk, "Introduction: Transnational Threats and Opportunities," in Globalization and Human Rights, ed. A. Brysk (Berkeley: University of California Press, 2002), 7.

2. Sarah Collison, "Globalisation and the Dynamics of International Migration: Implications for the Refugee Regime," New Issues in Refugee Research, Working Paper No. 1, Journal of Humanitarian Assistance (May 1999): 14, $<$ http://www.jha.ac/articles/u001.pdf> (accessed May 31, 2005).

3. Claudia Tazreiter, Asylum Seekers and the State: The Politics of Protection in a Security Conscious World (Hants: Ashgate Publishing: 2004), 1.

4. Anna Yeatman, "Global Ethics, Australian Citizenship and the 'Boat People': A Symposium," Journal of Sociology 39, no. 1 (2003): 19-20.

5. Michael Leach and Fethi Mansouri, Lives in Limbo; Voices of Refugees Under Temporary Protection (Sydney: University of New South Wales Press, 2004), 126.

6. B.S. Chimni, "Globalisation, Humanitarianism and the Erosion of Refugee Protection," Journal of Refugee Studies 13, no. 3 (2000): 243-263.

7. Jeff Crisp, "A New Asylum Paradigm? Globalisation, Migration and the Uncertain Future of the International Refugee Regime," New Issues in Refugee Research, Working Paper No. 100 (Geneva: UNHCR, 2003), 7.

8. Arthur C. Helton, The Price of Indifference, Refugees and Humanitarian Action in the New Century (Oxford: Oxford University Press, 2002), 9.

9. Matthew Gibney, The Ethics and Politics of Asylum: Liberal Democracy and the Response to Refugees (Cambridge: Cambridge University Press, 2004), 3.

10. Stephen Legomsky, "Secondary Refugee Movements and the Return of Asylum Seekers to Third Countries: The Meaning of Effective Protection," International Journal of Refugee Law 15, no. 4 (2003): 567-677. 
11. James C. Hathaway, "What's in a Label?" European Journal of Migration and Law 5 (2003).

12. For example, Maria Appelqvist, "Party Politics and the Bosnian Question: The Swedish Decision to Grant Permanent Residence," Journal of Ethnic and Migration Studies 26, no. 1 (2000): 93.

13. For example Jan-Paul Brekke, "The Dilemmas of Temporary Protection: The Norwegian Experience," Policy Studies 22, no. 1 (2001): 7.

14. Joan Fitzpatrick, "Temporary Protection of Refugees: Elements of a Formalized Regime," American Journal of International Law 94, no. 2 (2000): 1.

15. Hathaway, 1.

16. Fitzpatrick, 280.

17. Department of Immigration and Multicultural Affairs, Fact Sheet 64, Temporary Protection Visas, <http://www.immi. gov.au/media/fact-sheets/64protection.htm $>$ (accessed August 7, 2006).

18. Savitri Taylor, "Sovereign Power at the Border," Public Law Review 16 (2005).

19. Department of Immigration and Citizenship, Fact Sheet 68, Abolition of Temporary Protection Visas (TPVs) and Temporary Humanitarian Visas (THVs), and the Resolution of Status (Subclass 851) Visa, <http://www.immi.gov.au/ media/fact-sheets/68tpv_further.htm> (accessed August 12, 2009).

20. Danish Ministry of Foreign Affairs, Refugees and Other Foreigners in Denmark Seen in an International Perspective (2002), <http://www.um.dk/Publikationer/UM/English/ FactsheetDenmark/Refugees/html/chapter01.htm> (accessed May 22, 2008).

21. In order to maintain the anonymity of all participants, we are using pseudonyms throughout the discussion instead of the real names of all interviewees.

22. Lindsey Rubin, "Love's Refugees: The Effects of Stringent Danish Immigration Policies on Danes and Their NonDanish Spouses," Connecticut Journal of International Law 20 (2005): 320.

23. European Commission Against Racism and Intolerance, Third Report on Germany, (2005), <http://www.coe.int/t/e/ human_rights/ecri/1\%2Decri/2\%2Dcountry\%2Dby\%2D country_approach/germany/third_report_Germany.pdf> (accessed May 22, 2008).

24. Edith Montgomery and Anders Foldspang, "Predictors of the Authorities' Decision to Grant Asylum in Denmark," Journal of Refugee Studies 18, no. 4 (2005): 454-467.

25. Ibid., 454.

26. US Committee for Refugees and Immigrants (USCRI), Refugee Conditions By Country: Denmark, <http://www. refugees.org/worldmap.aspx?subm=19\&area=About\%20 Refugees $>$ (accessed May 23, 2008).

27. Karen Wren, "Refugee Dispersal in Denmark: From Macro- to Micro-Scale Analysis," International Journal of Population Geography 9, no. 1 (2003): 57-75.

28. Ibid.
29. Liza Schuster, The Use and Abuse of Political Asylum in Britain and Germany (London and Portland, OR: Frank Cass, 2003).

30. Ibid., 185.

31. Gibney, 103.

32. Wolfgang Bosswick, "Development of Asylum Policy in Germany," Journal of Refugee Studies 13, no. 1 (2000): 43-60.

33. Christian Joppke, Immigration and the Nation State: The United States, Germany and Great Britain (Oxford: Oxford University Press, 1999), 90.

34. US Committee for Refugees and Immigrants (USCRI), Refugee Conditions By Country: Germany, <http://www. refugees.org/worldmap.aspx?subm=19\&area $=$ About $\% 20$ Refugees $>$ (accessed May 23, 2008).

35. European Commission Against Racism and Intolerance (ECRI), Third Report on Germany, (2003), <http://www.coe. int/t/e/human_rights/ecri/1\%2Decri/2\%2Dcountry\%2Db y\%2Dcountry_approach/germany/third_report_Germany. pdf $>$ (accessed May 22, 2008).

36. Eric Leise, "Germany to Regularise 'Tolerated' Asylum Seekers," Migration Information Source, (Migration Policy Institute, 2007), <http://www.migrationinformation.org/ Feature/display.cfm?ID=593> (accessed May 24, 2008).

37. Ibid.

38. In Germany, interviews were conducted with staff of Flüchtlingsrat Berlin, the Centre for Treatment of Torture Victims, and Xenion, Berlin. In Denmark, interviews were conducted with staff of the Danish Institute for Human Rights, the Danish Refugee Council, the Research and Rehabilitation Centre for Torture Victims, and the Danish Red Cross.

39. For example, Leach and Mansouri.

40. Human Rights Watch, Letter to the German Government Expressing Concern over Policy of Revoking Refugee Status for Iraqi Refugees (2007), <http://hrw.org/english/ docs/2007/07/10/german16367_txt.htm> (accessed May 22, 2008).

41. Leach and Mansouri.

42. Danish Ministry of Foreign Affairs.

43. Brekke, 6 .

44. The Australian Liberal-National coalition parties-currently in opposition-have pledged to reintroduce TPVs if elected in the 2010 federal election.

45. Shakeh Momartin, Zachary Steel, Marianio Coello, Jorge Aroche, Derrick M. Silove, and Robert Brooks, "A Comparison of the Mental Health of Refugees with Temporary Versus Permanent Protection Visas," Medical Journal of Australia 185, no. 7 (October 2006): 357-361.

46. Derrick M. Silove and Zachary Steel, "Temporary Protection Visas Compromise Refugees' Health: New Research," media releasenUniversity of New South Wales, Sydney (January 30, 2004), <http://www.unsw.edu.au/news/pad/ articles/2004/jan/TPV_HealthMNE.html> (accessed May 22, 2006). 
47. Sabine Luebben, "Testimony Work with Bosnian Refugees: Living in Legal Limbo," British Journal of Guidance and Counselling 31, no. 4 (2003): 399.

Fethi Mansouri holds a chair in Migration and Intercultural Studies and is the director of the Research Institute for Citizenship and Globalisation at Deakin University.
Michael Leach is a senior lecturer in politics at Swinburne University of Technology's Faculty of Life and Social Sciences.

Amy Nethery is a doctoral candidate at Deakin University's School of International and Political Studies.

(c) Fethi Mansouri, Michael Leach and Amy Nethery, 2009. This open-access work is licensed under a Creative Commons AttributionNonCommercial 4.0 International License, which permits use, reproduction and distribution in any medium for non-commercial purposes, provided the original author(s) are credited and the original publication in Refuge: Canada's Journal on Refugees is cited. 